COSTING:Journal of Economic, Business and Accounting

Volume 4 Nomor 2, Juni 2021

e-ISSN : 2597-5234

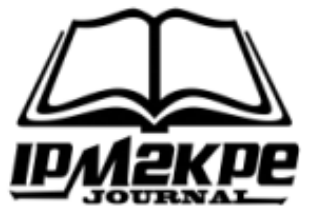

\title{
DINAMIKA HUKUM PERPAJAKAN DI INDONESIA DITINJAU DARI UNDANG-UNDANG NOMOR 28 TAHUN 2009 TENTANG PAJAK DAERAH DAN DISTRIBUSI DAERAH
}

\section{LEGAL DYNAMICS OF TAXATION IN INDONESIA ASSESSED FROM LAW NUMBER 28 OF 2009 CONCERNING REGIONAL TAXES AND REGIONAL DISTRIBUTION}

\author{
Moza Dela Fudika1, Rosyidi Hamzah ${ }^{2}$ \\ Universitas Islam Riau ${ }^{1,2}$ \\ mozadelafudika@,law.uir.ac.id ${ }^{1}$
}

\begin{abstract}
Changes in tax regulation policies as an implication of regional autonomy in Indonesia starting from Law Number 18 of 1997 concerning Regional Taxes and Regional Levies, then amended by Law Number 34 of 2000 concerning Amendments to Law Number 18 of 1997 concerning Taxes Regions and Regional Retribution. This regulation was later replaced by Law Number 28 of 2009 concerning Regional taxes and Regional Levies. Of the three regulations, legal dynamics occur that lead from decentralized to centralized. The research method in this study uses the normative legal method. From the results of the study, it is found that the dynamics of taxation law in Indonesia in terms of law number 28 of 2009 concerning regional taxes and regional distribution have experienced legal changes in terms of types of taxes, discretionary rate setting, and the nature of determining the type of tax of the law prevailing previously which led to a decentralized to centralized nature as well as a change in tax determination policy from an open list system to a closed list system.
\end{abstract}

Keyword : Legal Dynamics, Taxation, Regional Taxes And Regional Distribution

\begin{abstract}
ABSTRAK
Perubahan regulasi kebijakan pengaturan pajak sebagai bentuk implikasi otonomi daerah di Indonesia dimulai dari Undang-undang Nomor 18 Tahun 1997 tentang Pajak Daerah dan Retribusi Daerah, kemudian dirubah dengan Undang- undang Nomor 34 Tahun 2000 tentang Perubahan Atas Undang-undang Nomor 18 Tahun 1997 tentang Pajak Daerah dan Retribusi Daerah. Aturan tersebut kemudian diganti dengan UU Nomor 28 tahun 2009 tentang pajak Daerah dan Retribusi Daerah. Dari ketiga regulasi tersebut terjadi dinamika hukum yang mengarah dari desentralistik menuju sentralistik. Metode penelitian dalam penelitian ini menggunakan metode hukum normatif. Dari hasil penelitian diperoleh bahwa Dinamika hukum perpajakan di indonesia ditinjau dari undang-undang nomor 28 tahun 2009 tentang pajak daerah dan distribusi daerah mengalami perubahan-perubahan hukum yang ditinjau dari jenis pajak, diskresi penetapan tarif, dan sifat penetapan jenis pajak dari undang-undang yang berlaku sebelumnya yang mengarah kepada sifat desentralistik menuju sentralistik serta berubahnya kebijakan penetapan pajak dari open list system kepada clos list system.
\end{abstract}

Kata Kunci : Dinamika Hukum, Perpajakan, Pajak Daerah Dan Distribusi Daerah 


\section{PENDAHULUAN}

Indonesia adalah Negara hukum yang merdeka dan berdaulat yang memiliki cita-cita dalam penyelenggaraan pemerintahannya, tujuan tersebut sebagaimana yang tertuang dalam Pembukaan UUD Negara Republik Indonesia Tahun 1945 bahwa bertujuan untuk melidungi segenap bangsa Indonesia dan untuk memajukan kesejahteraan umum, mencerdaskan kehidupan bangsa dan ikut melaksanakan ketertiban dunia yang berdasarkan kemerdekaan, perdamaian abadi, dan keadilan sosial.

Reformasi perpajakan di Indonesia pada dasarnya telah dimulai sejak tahun 1983 yang ditandai dengan Indonesia telah memiliki peraturan sendiri yang berdampak kepada bangsa Indonesia tidak lagi menggunakan produk hukum Belanda dalam bidang perpajakan. Perubahan ini mengarah kepada pembangunan hukum dibidang proses dan materinya begitu juga dengan pelaksanaannya termasuk penegasan fungsi lembaga dan membina para penegak hukumnya (Thohari, 2018).

Peran pajak bagi ekonomi suatu negara hanya berujung pada 2 (dua) kebijakan, yakni alokasi dan distribusi. Kebijakan alokasi merujuk pada pentingnya pajak untuk membiayai barang-barang yang tidak sanggup disediakan oleh individu privat, sedangkan kebijakan distribusi fokus pada pajak sebagai skema pendistribusian kesejahteraan individu-individu dalam masyarakat (Prasetyia, 2012)

$$
\text { Reformasi perpajakan di }
$$

Indonesia ditandai dengan diubahnya sistem perpajakan lama dari official assessment system menjadi self assessment system. Bahwa sistem self assesement ialah memberikan kepercayaan kepada wajib pajak untuk menghitung sendiri, menyetor jumlah pajaknya sendiri, mengisi dan melaporkan pajaknya sendiri sesuai perhitungan dan data yang dimiliki sendiri oleh wajib pajak (Ilyas, 2010). Dengan adanya kebijakan sistem self assessment system ini diharapkan dapat menumbuhkan kesadaran dan kepedulian untuk melunasi pajak.

Indonesia sebagai negara hukum, diwajibkan untuk mengatur lebih lanjut bidang perpajakan berdasarkan atas hukum, maka segala tindakan termasuk bidang perpajakan harus didasarkan atas aturan hukum yang berlaku. Berdasarkan ketentuan tersebut, pengaturan pajak harus dibuat sesuai proses pembuatan undang-undang. Di dalam Pasal 23A Undang-Undang Dasar 1945 secara tegas dinyatakan bahwa "segala pajak dan pungutan lain yang bersifat memaksa untuk keperluan negara berdasarkan undang-undang". Berdasarkan Pasal tersebut, maka selanjutnya ditetapkan undang-undang yang mengatur tentang pajak daerah (Arya, 2018).

Seiring dengan bergulirnya otonomi daerah, telah merubah paradigma penyelenggaraan pemerintahan di daerah dimana kekuasaan yang bersifat sentralistik berubah menjadi desentralistik dengan memberikan otonomi yang seluasluasnya sebagaimana diatur dalam Undang-undang Nomor 22 Tahun 1999 tentang Pemerintahan Daerah kemudian diganti dengan Undang-undang Nomor 32 Tahun 2004, Terkakhir dibentuk Undang-Undang Nomor 23 Tahun 2014 tentang Pemerintahan Daerah. Perubahan kebijakan pengaturan pemerintahan daerah tersebut diselaraskan dengan adanya perubahan kebijakan terhadap pajak dan retribusi daerah sebagai 
landasan bagi daerah dalam menggali potensi pendapatan daerah khususnya pendapatan asli daerah, yakni Undangundang Nomor 18 Tahun 1997 tentang Pajak Daerah dan Retribusi Daerah, kemudian dirubah dengan Undangundang Nomor 34 Tahun 2000 tentang Perubahan Atas Undang-undang Nomor 18 Tahun 1997 tentang Pajak Daerah dan Retribusi Daerah. Aturan tersebut kemudian diganti dengan UU Nomor 28 tahun 2009 tentang pajak Daerah dan Retribusi Daerah (Achmad, 2015).

Berdasarkan beberapa regulasi yang pernah dan sedang berlaku terkait pajak daerah dan retribusi daerah tersebut, terdapat dinamika yang mengarah kepada perubahan sistem perpajakan daerah tersebut yang mengarah dari desentralisasi menuju kepada sentralisasi terhadap pajak daerah. Dalam UU Nomor 18 Tahun 1997 pemerintah daerah tidak berhak menetapkan pajak daerah dan retribusi daerah karena sepenuhnya ditetapkan oleh pemerintah pusat (SentralistikOtoriter). Dalam UU Nomor 34 Tahun 2000 bahwa pajak dan retribusi daerah ditetapkan pemerintah pusat (Sentralistik) dan Kabupaten/Kota boleh menetapkan jenis pajak daerah dengan Peraturan Daerah, diluar yang sudah ditetapkan pemerintah pusat (Desentralistik) yang menganut open list sistem. Sedangkan dalam UU Nomor 28 Tahun 2009 bahwa pajak dan retribusi daerah hanya ditetapkan pemerintah (Sentralistik) dalam hal penetapan jenis pajak daerah peraturan ini menganut clos list system.

\section{METODE PENELITIAN}

Metode Penelitian yang digunakan adalah metode penelitian hukum normatif. Ada 3 (tiga) tahap analisis pada penelitian ini, yakni tahap pertama, menginventarisasi data sekunder, guna diperiksa kelengkapan dan kejelasannya. Tahap kedua, data kepustakaan ditarik kesimpulan sebagai jawaban rumusan masalah yang diteliti. Analisis dilakukan secara kualitatif. Tahap ketiga, penarikan kesimpulan dilakukan dengan menggunakan metode deduktif atau metode penalaran merupakan metode untuk menarik kesimpulan dari hal-hal umum ke hal-hal khusus

Data yang digunakan adalah data sekunder yang terdiri dari bahan hukum primer berupa peraturan perundangundangan yang terkait pembahasan seperti Undang-Undang Dasar Negara Republik Indonesia Tahun 1945, Undang-Undang Nomor 18 Tahun 1997 tentang Pajak Daerah dan Retribusi Daerah, Undang-Undang Nomor 34 Tahun 2000 Tentang Perubahan Atas Undang-Undang Republik Indonesia Nomor 18 Tahun 1997 tentang Pajak Daerah dan Retribusi Daerah, UndangUndang Nomor 28 Tahun 2009 Tentang Pajak Daerah dan Retribusi Daerah. Aapun bahan-bahan hukum sekunder terdiri dari jurnal-jurnal, buku-buku dan pendapat para ahli yang berkenaan dengan pajak dan retribusi daerah maupun sistem perpajakan secara umum.

\section{HASIL DAN PEMBAHASAN}

Karakter hukum yang terbentuk di Indonesia tidak terlepas dari kemauan politik (political will) pemerintah, sebab hukum adalah merupakan produk politik pemerintah yang berkuasa, walaupun kenyataannya tidak seluruhnya hukum sebagai produk politik, namun sebagian merupakan produk sosial, budaya, ekonomi dan hukum. Di mana hukum merupakan kepentingan dan selalu ditemukan pada posisi yang tidak netral. 
Kepentingan memiliki kaitan yang sangat erat dengan kebijakan yang ditetapkan oleh pemerintah, baik kebijakan tersebut pro terhadap rakyat maupun tidak pro terhadap rakyat.

Dalam khasanah perpajakan terdapat 5 (lima) prinsip umum yang sudah mapan, yakni: Four Maxims dari Adam Smith, General Principle of Taxation dari John Stuart Mill, Principle of Taxation dari Francis A. Walker, Principle of Apportionment dari Henry C. Adams, dan The Fundamental Problems dari Edwin R.A. Seligman.7 Ide penting dari kelima prinsip umum perpajakan bukan pada pajak sebagai penutup biaya operasional bernegara (budgetair function)

Ide penting dari kelima prinsip umum perpajakan terletak pada kehatihatian dalam memungut pajak. Ini berangkat dari situasi bahwa pajak mengakibatkan nestapa (deadweight loss) bagi individu dalam pertukaran (market). Ini bermuara pada konsep pajak yang baik yang menempatkan pajak menuju Fungsi Kesejahteraan Sosial. (Guzy, 2017). Hal ini memiliki Konsekuensi bahwa dalam sistem pemungutan perpajakan tetap mengedepankan prinsip netralitas dan efisiensi menjadi persyaratan mutlak dalam pemungutannya. Keduanya menjelma pada perpajakan optimal (Johan, 2019)

Selain itu, sistem perpajakan yang demokatis sebenarnya bukan menyangkut teknik bagaimana rakyat mau untuk membayar pajak atau memasukkan pajak ke dalam kas negara, namun yang lebih penting adalah reformasi regulasi perpajakan yang seimbang antara hak dan kewajiban rakyat dengan pemerintah dengan orientasi terhadap kepentingan rakyat serta reformasi anggaran yang selama ini dikhawatirkan dan dicurigai pemanfaatannya.

Pajak sebagai penopang penerimaan daerah akan menjadi tidak optimal dan bahkan menjadi beban bagi daerah maupun nasional, apabila pemerintah daerah dalam membuat regulasi dan kebijakan tidak sinkron dengan kebijakan perpajakan nasional. Iklim investasi daerah dan nasional menjadi tidak kondusif. Masyarakat juga menjadi enggan untuk membayar pajak, melakukan penghindaran pajak maupun penyelundupan pajak, karena pajak menjadi beban bagi masyarakat. (Adiyanta, 2019)

Pembaharuan sistem perpajakan daerah dimulai pada tahun 1997 dengan menerbitkan Undang-Undang Nomor 18 Tahun 1997 untuk membangun sistem pungutan yang sederhana, adil, efektif. Pada era ini (orde baru) pemungutan obyek pajak dapat ditambah melalui Peraturan Pemerintah selain yang ditetapkan oleh undang-undang, yang artinya memberikan kewenangan kepada pemerintah pusat (sentralistik) untuk menambah obyek pajak daerah provinsi maupun kabupaten/kota selain yang diatur dalam Undang-Undang. Dalam Undang-Undang Nomor 18 Tahun 1997 ini, pembagian pajak daerah terbagi atas pajak daerah provinsi dan pajak daerah kabupaten/kota.

Seiring dengan lahirnya UndangUndang Nomor 22 Tahun 1999 tentang Pemerintahan Daerah dan UndangUndang Nomor 25 Tahun 1999 tentang Perimbangan Keuangan Pusat dan Daerah, telah mengubah secara signifikan hubungan antara pusat dan daerah yang sebelumnya sentralistik berubah menjadi desentralistik. Hal itu berdampak pada perubahan Undang-Undang Nomor 18 Tahun 1997 menjadi Undang-Undang 
Nomor 34 Tahun 2000 yang merupakan penyempurnaan aturan sebelumnya.

Pasal 2 ayat (4) Undang-Undang Nomor 34 Tahun 2000 Tentang Pajak Daerah dan Retribusi Daerah, dinyatakan bahwa dalam peraturan daerah dapat ditetapkan jenis pajak kabupaten/kota selain ditetapkan dalam ayat(2) yang memenuhi kriteria yaitu, terdapat di wilayah daerah kabupaten/kota yang bersangkutan serta hanya melayani masyarakat diwilayah daerah kabupaten/kota yang bersangkutan, objek pajak bukan merupakan objek pajak provinsi dan/atau pajak pusat, potensinya memadai dan tidak memberikan dampak ekonomi yang negativ, memperhatikan aspek keadilan dan kemampuan masyarakat, menjaga kelestarian lingkungan.

Kewenangan daerah dalam memungut jenis objek Pajak Daerah dan Distribusi Daerah yang ditetapkan dalam Undang- Undang Nomor 34 Tahun 2000 bersifat open list. Kondisi ini memberi peluang bagi Pemda untuk menciptakan pungutan baru diluar jenis pajak/retribusi yang telah ditetapkan dalam UU Nomor 34 Tahun 2000 juncto Peraturan Pemerintah Nomor 65 Tahun 2001 tentang Pajak Daerah dan Peraturan Pemerintah Nomor 66 Tahun 2001 tentang Retribusi Daerah. (Puspita, 2016) Dengan adanya kebijakan open list sistem yang semula diharapkan akan memberikan peluang pemasukan kepada daerah namun permasalahan banyak timbul diantaranya : banyak pajak dan retribusi daerah baru yang tidak sesuai kriteria karena kurang memahami/mengabaikan kriteria, penetapan biaya tinggi, serta pengawasan yang represif.

Melihat Undang-Undang Nomor 34 Tahun 2000 tidak maksimal maka lahirlah Undang-Undang Nomor 28 Tahun 2009. Dalam Undang-Undang Nomor 28 Tahun 2009 tentang Pajak Daerah dan Retribusi Daerah ini, daerah dilarang memungut pajak selain jenis pajak yang telah ditetapkan dalam Undang-Undang ini. Mekanisme pengawasan juga berubah dari represif menjadi preventif. Setiap peraturan daerah tentang pajak daerah dan retribusi daerah sebelum dilaksanakan harus mendapat persetujuan terlebih dahulu dari pemerintah. Selain itu, daerah menetapkan kebijakan di bidang pajak daerah dan retribusi daerah yang melanggar ketentuan peraturan perundang-undangan yang lebih tinggi akan dikenakan sanksi berupa penundaan dan/atau pemotongan dana alokasi umum dan/atau dana bagi hasil atau restitusi.

Adapun perubahan-perubahan yang terjadi dari Undang-Undang Nomor 18 Tahun 1997 dengan Undang-Undang Nomor 34 Tahun 2000 dan UndangUndang Nomor 28 Tahun 2009 antara lain terlihat dalam tabel dibawah ini :

Tabel 1 Perubahan Jenis Pajak Daerah

\begin{tabular}{|c|c|c|c|}
\hline NO & $\begin{array}{c}\text { UU No.18 } \\
\text { Tahun } \\
1997\end{array}$ & $\begin{array}{c}\text { UU No.34 Tahun } \\
2000\end{array}$ & $\begin{array}{c}\text { UU No.28 } \\
\text { Tahun } \\
2009\end{array}$ \\
\hline 1 & $\begin{array}{l}\text { Pajak } \\
\text { Kendaraan } \\
\text { Bermotor }\end{array}$ & $\begin{array}{lr}\text { Pajak Kendaraan } \\
\text { Bermotor dan } \\
\text { Kendaraan di Atas } \\
\text { Air }\end{array}$ & $\begin{array}{l}\text { Pajak } \\
\text { Kendaraan } \\
\text { Bermotor }\end{array}$ \\
\hline 2 & $\begin{array}{l}\text { Pajak Bea } \\
\text { Balik } \\
\text { Nama } \\
\text { Kendaraan } \\
\text { Bermotor }\end{array}$ & $\begin{array}{lr}\text { Pajak Bea Balik } \\
\text { Nama Kendaraan } \\
\text { Bermotor r dan } \\
\text { Kendaraan di Atas } \\
\text { Air }\end{array}$ & $\begin{array}{l}\text { Pajak Bea } \\
\text { Balik } \\
\text { Nama } \\
\text { Kendaraan } \\
\text { Bermotor }\end{array}$ \\
\hline 3 & $\begin{array}{l}\text { Pajak } \\
\text { Bahan } \\
\text { Bakar } \\
\text { Kendaraan } \\
\text { Bermotor }\end{array}$ & $\begin{array}{l}\text { Pajak Bahan Bakar } \\
\text { Kendaraan } \\
\text { Bermotor dan } \\
\text { Kendaraan di Atas } \\
\text { Air }\end{array}$ & $\begin{array}{l}\text { Pajak } \\
\text { Bahan } \\
\text { Bakar } \\
\text { Kendaraan } \\
\text { Bermotor }\end{array}$ \\
\hline 4 & - & $\begin{array}{l}\text { Pajak Pengambilan } \\
\text { dan Pemanfaatan } \\
\text { Air Bawah Tanah } \\
\text { dan Air Permukaan }\end{array}$ & $\begin{array}{l}\text { Pajak Air } \\
\text { Permukaan }\end{array}$ \\
\hline
\end{tabular}




\begin{tabular}{cccc}
\hline NO & $\begin{array}{c}\text { UU No.18 } \\
\text { Tahun } \\
1997\end{array}$ & $\begin{array}{c}\text { UU No.34 Tahun } \\
2000\end{array}$ & $\begin{array}{c}\text { UU No.28 } \\
\text { Tahun } \\
\end{array}$ \\
& & & 2009 \\
& - & - & \\
\hline & & & Pajak \\
& & & Rokok \\
\hline
\end{tabular}

Sumber Data : UU No.18 Tahun 1997, UU No.34 Tahun 2000, UU No.28 Tahun 2009 tentang Pajak Daerah dan Distribusi Daerah

Dalam beberapa kali revisi UndangUndang tersebut, terdapat perubahanperubahan diantaranya terdapat penambahan jenis pajak provinsi yang sebelumnya hanya ada 3 (tiga) bertambah menjadi 4 (empat) dan undang-undang terakhir bertambah kembali menjadi 5 (lima) yaitu pajak rokok. Namun, meskipun terdapat penambahan dari jenis jumlah, terdapat perubahan subpajak tertentu dari Undang-Undang Nomor 34 Tahun 2000 ke Undang-Undang Nomor 28 Tahun 2009. Misalnya, dalam Undang-Undang Nomor 34 Tahun 2000 dalam hal Pajak Kendaraan Bermotor dan Kendaraan di Atas Air, berubah menjadi Pajak Kendaraan Bermotor sebagaimana yang disebutkan di dalam UndangUndang Nomor 28 Tahun 2009.

Tabel 2 Perbedaan Diskresi Penetapan Tarif

\begin{tabular}{|c|c|c|c|c|}
\hline & Tarif & $\begin{array}{c}\text { UU No.18 } \\
\text { Tahun } 1997\end{array}$ & $\begin{array}{c}\text { UU No.34 } \\
\text { Tahun } \\
2000\end{array}$ & $\begin{array}{c}\text { UU No.28 } \\
\text { Tahun } 2009\end{array}$ \\
\hline 1 & $\begin{array}{l}\text { Pajak } \\
\text { Provinsi }\end{array}$ & $\begin{array}{l}\text { Ditetapkan } \\
\text { dengan } \\
\text { Peraturan } \\
\text { Pemerintah } \\
\text { (diberlakukan } \\
\text { seragam } \\
\text { diseluruh } \\
\text { Indonesia) }\end{array}$ & $\begin{array}{l}\text { Ditetapkan } \\
\text { dengan } \\
\text { Peraturan } \\
\text { Pemerintah } \\
\text { (diberlakuk } \\
\text { an seragam } \\
\text { di seluruh } \\
\text { Indonesia) }\end{array}$ & $\begin{array}{l}\text { Ditetapkan } \\
\text { dengan } \\
\text { Peraturan } \\
\text { Daerah (tidak } \\
\text { boleh } \\
\text { melampaui } \\
\text { undang- } \\
\text { undang) }\end{array}$ \\
\hline 2 & $\begin{array}{l}\text { Pajak } \\
\text { Kabupat } \\
\text { en/Kota }\end{array}$ & $\begin{array}{l}\text { Ditetapkan } \\
\text { dengan } \\
\text { Peraturan } \\
\text { Daerah (tidak } \\
\text { boleh } \\
\text { melampaui } \\
\text { Undang- } \\
\text { Undang) }\end{array}$ & $\begin{array}{l}\text { Ditetapkan } \\
\text { dengan } \\
\text { Peraturan } \\
\text { Daerah } \\
\text { (tidak } \\
\text { boleh } \\
\text { melampaui } \\
\text { Undang- } \\
\text { Undang) }\end{array}$ & $\begin{array}{l}\text { Ditetapkan } \\
\text { dengan } \\
\text { Peraturan } \\
\text { Daerah (tidak } \\
\text { boleh } \\
\text { melampaui } \\
\text { Undang- } \\
\text { Undang) }\end{array}$ \\
\hline
\end{tabular}

Jika dilihat tabel di atas menurut Undang-Undang Nomor 18 Tahun 1977 dan Undang-Undang Nomor 34 Tahun 2000 bahwa tarif pajak provinsi ditetapkan dengan Peraturan Pemerintah (diberlakukan seragam di seluruh Indonesia sedangkan tarif pajak kabupaten/kota ditetapkan dengan Peraturan Daerah (tidak boleh melampaui undang-undang). Jika dilihat dari Undang-Undang Nomor 28 Tahun 2009 maka sistem penetapan tarif pajak ditetapkan dengan Peraturan Daerah (tidak boleh melampaui undang-undang) baik pajak provinsi ataupun pajak kabupaten/kota, disini terlihat persamaan dan juga perbedaan bahwa UndangUndang Nomor 18 Tahun 1997 dan Undang-Undang Nomor 34 Tahun 2000 dalam hal penetapan nilai tarif pajak lebih bersifat sentralistik sedangkan daerah kabupaten/kota bersifat desentralistik, dan undang-undang Nomor 28 Tahun 2009 dalam hal penetapan pajak Provinsi dan Kabupaten/Kota bersifat desentralistik.

Tabel 3 Perbandingan Sifat Penetapan Pajak dan Retribusi

\begin{tabular}{|c|c|c|c|}
\hline & $\begin{array}{l}\text { UU No.18 } \\
\text { Tahun } \\
1997\end{array}$ & UU No.34 Tahun 2000 & $\begin{array}{l}\text { UU No.28 } \\
\text { Tahun } \\
2009\end{array}$ \\
\hline 1 & $\begin{array}{l}\text { Pajak dan } \\
\text { Retribusi } \\
\text { Daerah } \\
\text { ditetapkan } \\
\text { oleh } \\
\text { Pemerintah } \\
\text { Pusat } \\
\text { (Sentralistik) } \\
\text { dan dapat } \\
\text { ditambah } \\
\text { melalui } \\
\text { Peraturan } \\
\text { Pemerintah }\end{array}$ & $\begin{array}{l}\text { Pajak dan Retribusi Daerah } \\
\text { ditetapkan pemerintah, } \\
\text { (Sentralistik) } \\
\text { Kabupaten/Kota dengan } \\
\text { Peraturan Daerah boleh } \\
\text { menetapkan jenis pajak } \\
\text { daerah, diluar yang sudah } \\
\text { ditetapkan } \\
\text { pemerintah.(Desentralistik) }\end{array}$ & $\begin{array}{l}\text { Pajak } \\
\text { Daerah dan } \\
\text { Retribusi } \\
\text { Daerah } \\
\text { ditetapkan } \\
\text { pemerintah } \\
\text { (Sentralistik) }\end{array}$ \\
\hline \multicolumn{4}{|c|}{$\begin{array}{l}\text { Sumber Data: UU No.18 Tahun 1997, UU No.34 Tahun } \\
\text { 2000, UU No.28 Tahun } 2009 \text { tentang Pajak Daerah dan } \\
\text { Distribusi Daerah }\end{array}$} \\
\hline
\end{tabular}


Dilihat dari tabel di atas, bahwa Undang-Undang Nomor 18 Tahun 1997 pemerintah daerah tidak berhak menetapkan pajak daerah dan retribusi daerah bahwa jenis pajak daerah dan retribusi daerah ditetapkan oleh pemerintah pusat (Sentralistik Otoriter). Pemberlakuan Undang-Undang Nomor 18 Tahun 1997 juga belum memberikan dampak besar dari penerimaan daerah diakibatkan tahun 1997-2000 Indonesia mengalami krisis ekonomi, dalam hal penetapan jenis pajak daerah peraturan ini tergolong produk hukum yang elitis kondisi ini dapat dipahami karena saat itu format politik masa orde baru yang otoriter.

Kemudian diikuti dengan Undang-Undang Nomor 34 Tahun 2000 bahwa pajak dan retribusi daerah ditetapkan pemerintah pusat, dan Kabupaten/Kota boleh menetapjan jenis pajak daerah dengan Peraturan Daerah, di luar yang sudah ditetapkan pemerintah pusat (desentralistik) dalam hal penetapan jenis pajak daerah peraturan ini menganut open list sistem.

Sedangkan dalam UndangUndang Nomor 28 Tahun 2009 bahwa pajak dan retribusi daerah ditetapkan pemerintah (Sentralistik) dalam hal penetapan jenis pajak daerah peraturan ini menganut clos list system untuk mengantisipasi terjadinya penyimpangan pelaksanaan asas-asas otonomi daerah. Namun, jika dianalisis lebih lanjut lahirnya aturan Undang-Undang Nomor 28 Tahun 2009 memangkas sisi lain dari asas desentralisasi yang memberikan kebebasan bagi tiap-tiap daerah untuk mengatur dan mengurus daerah masingmasing sesuai dengan kemampuan dan ketersediaan potensi yang ada di masingmasing daerah.

\section{PENUTUP}

Kesimpulan

Dinamika hukum perpajakan di indonesia ditinjau dari undang-undang nomor 28 tahun 2009 tentang pajak daerah dan distribusi daerah mengalami perubahan-perubahan hukum yang ditinjau dari jenis pajak, diskresi penetapan tarif, dan sifat penetapan jenis pajak dari undang-undang yang berlaku sebelumnya yang mengarah kepada sifat desentralistik menuju sentralistik serta terjadinya perubahan-perubahan tersebut juga dipengaruhi oleh konfigurasi politik yang berlaku pada tiap masanya, seperti lahirnya Undang-Undang Nomor 18 Tahun 1997 lebih mengarah kepada sentralistik karna pada masa itu undangundang tersebut dibentuk pada era orde baru (hukum berkarakter ortodoks).

\section{Saran}

Kedepannya regulasi yang mengatur mengenai pajak daerah dan distribusi daerah diharapkan memenuhi kebutuhan hukum yang seharusnya bagi tiap-tiap daerah sehingga terwujudnya asas desentralisasi sebagaimana yang disebutkan dalam Undang-Undang Pemerintahan Daerah bahwa daerah dapat mengatur dan mengurus urusan rumah tangga daerah berdasarkan kemampuan dan kebutuhan masing-masing daerah yang tetap mengacu kepada peraturan perundang-undangan di Indonesia.

\section{DAFTAR PUSTAKA}

Achmad. (2015). Harmonisasi Pengaturan Pajak Daerah dalam Kerangka Desentralisasi Fiskal dan Otonomi Daerah. Yustisia, 12(3). 
Adiyanta, F. S. (2019). Karakteristik Responsif Peraturan Daerah tentang Pajak-Pajak Daerah sebagai Representasi dan Partisipasi Kehendak Publik. Adminitrative Law \& Governance Journal, 38(2).

Arya, G. (2018). Eksistensi Pajak Daerah Sebagai Wujud Pelaksanaan Otonomi Daerah Dalam Kerangka Good Financial Governance. Media Luris, 25(7).

Ilyas, W. (2010). Hukum Pajak. Jakarta: Salemba Empat.

Guzy. (2017). The principles of tax law equality in the context of direct taxation. Journal of Economics \& Management, 72-73.

Johan, A. (2019). Perpajakan Optimal dalam Perspektif Hukum Pajak. Jurnal Magister Hukum Udayana, 31(9).

Prasetyia. (2012). Rekonstruksi Sistem Fiskal Nasional Dalam Bingkai Konstitusi. Journal of Indonesian Applied Economics, 14(2).

Puspita, A. F. (2016). Analisis Penetapan Target Penerimaan Pajak Daerah. Jurnal Administtrasi dan Bisnis, 30.

Thohari, A. A. (2018). Epistemologi Pajak, Perspektif Hukum Tata Negara Taxes Epistemology, Constitutional Law Perspective. Jurnal Legislasi Indonesia, 8(1), 69-78. 